\title{
NARRAR CON FILTROS: LA IMAGEN COMO PARATEXTO DEL MICRORRELATO EN INSTAGRAM
}

\author{
Basilio Pujante Cascales \\ Universidad de Murcia \\ bpujante@um.es
}

Resumen: Las imágenes han sido un paratexto muy interesante pero poco utilizado por la minificción española. Son pocos pero muy relevantes los casos en los que los microrrelatos han sido acompañados por fotografías o ilustraciones. Sin embargo, en la literatura hipermedial la situación es diferente y el autor de minicuentos puede usar con más sencillez imágenes como paratextos, especialmente en redes sociales como Instagram. En este artículo analizaremos las diferencias entre el uso de la imagen como paratexto en el microrrelato publicado en papel frente al publicado en internet, centrándonos en concreto en Instagram.

Palabras clave: microrrelato, minificción, paratextualidad, ciberliteratura, redes sociales.

\section{NARRATING WITH FILTERS: THE IMAGE AS A PARATEXT OF THE FLASH FICTION IN INSTAGRAM}

\begin{abstract}
The images have been a very interesting paratext, but not often used at the Spanish minifiction. There are few but very relevant cases in which the flash fictions have been accompanied by pictures or illustrations. However, in electronic literature the situation is different and the author of microfictions can more easily use images as paratexts, especially on social networks such as Instagram. In this article we will analyze the differences between the use of the image as a paratext in the flash fictions published on paper versus the one published on the internet, focusing specifically on Instagram.
\end{abstract}

Keywords: flash fiction, microfiction, paratextuality, electronic literature, social networking.

DOI: https://doi.org/10.24029/1ejana.2022.15.3553

Recibido: el 26 de agosto de 2021

Aceptado: el 30 de noviembre de 2021

Publicado: el 25 de febrero de 2022 


\section{Introducción}

En el principio fue el texto. La crítica literaria se centró durante un gran periodo de tiempo única y exclusivamente en aquello que formaba la corporeidad (permítaseme la metáfora) de la obra literaria, dejando de lado aquellos aspectos que se consideraban (convirtiendo la metáfora inicial en alegoría) en meros adornos externos. Sin embargo, en las décadas centrales del siglo XX y gracias a una manera más integral de entender la literatura, los elementos que acompañan al texto que va desde la palabra inicial hasta el punto final comenzaron a tenerse en cuenta y a ser valorados como aspectos fundamentales en esa comunicación particular que se produce en la literatura. Gérard Genette agrupó todos estos elementos que acompañan a la "obra en sí" en la "paratextualidad", una de las cinco categorías de la transtextualidad (Genette, 1989).

Los paratextos, entre los que se incluyen los títulos, las dedicatorias, las notas al pie de página, las cubiertas, etc., poseen un carácter un tanto paradójico: por un lado, se les considera ajenas al texto en sí, pero poseen una función primordial al actuar de umbral, presentación o, a veces incluso, de aclaración del significado de la obra. Esta última función es la que poseen muchos títulos, el paratexto más relevante tradicionalmente, que ofrecen luz sobre textos ambiguos o polisémicos. Especialmente útiles son los títulos en géneros con cierta tendencia a la metáfora, la poesía, o a la elipsis, el microrrelato. ${ }^{1}$ En este último caso, los paratextos en general y los títulos en particular suelen actuar como claves que el autor ofrece al lector para aclarar relatos que por su extrema concisión y el frecuente uso de la intertextualidad suelen ofrecer dificultades de comprensión, tal y como analicé en un artículo anterior (Pujante Cascales, 2008).

Pero ¿qué ocurre con las imágenes? Se trata, por supuesto y como también indica Genette, de elementos paratextuales que pueden entablar una relación directa con la trama del microrrelato y que, más allá de la función presentadora del conjunto que poseen las de la cubierta, pueden ofrecer muchas posibilidades a los autores de este género. En este artículo me ocuparé, en primer lugar, de la importancia que poseen las imágenes en la minificción publicada en papel, para después analizar las fotografías, dibujos y cuadros que acompañan a microrrelatos en internet $\mathrm{y}$, en particular, en Instagram, la red social iconográfica por excelencia. En este último caso, la imagen y el texto adquieren una relación simbiótica, por lo que la primera puede llegar a abandonar su función paratextual y se crean híbridos multimediales.

\section{La imagen como paratexto en la minificción}

Tal y como advertíamos en la introducción, los títulos adquieren en la minificción una importancia capital por el diálogo que a menudo establecen con la propia narración. Además de otras funciones como apuntar la referencia intertextual presente en el micorrelato ("Otro dinosaurio" de Eduardo Berti), poner el foco en un elemento que será importante en el texto ("El misántropo" de Ángel Olgoso) o definir genéricamente la obra ("Homo crisis [cuento derridiano]" de David Roas), el título puede a veces predisponer al lector hacia una

\footnotetext{
${ }^{1}$ Utilizaré durante todo el artículo los términos "microrrelato", "microcuento" y "minicuento" como sinónimos; por su parte, considero el término "minificción” como un hiperónimo.
} 
interpretación del minicuento que subvertirá el final con un giro inesperado que ofrezca una nueva perspectiva. Es lo que ocurre, por ejemplo, en el excelente microrrelato de Fernando Iwasaki titulado "La silla eléctrica" (Iwasaki, 2004: 56); tras este definitorio paratexto, el lector comienza a leer una historia sobre un condenado que es dirigido hacia esta cruel forma de ajusticiamiento. Sin embargo, justo al final se descubrirá que en realidad se trata de un paciente particularmente temeroso que se dirige a la consulta de su dentista. Este desenlace despoja al relato de la supuesta brutalidad de una primera lectura y produce una resignificación del título, que, aprovechando su carácter polisémico, define ahora esa silla llena de instrumentos y de luces propia de los odontólogos.

Como se puede observar con este ejemplo, algunos autores emplean con perspicacia las posibilidades que ofrece el título en la minificción. Por el contrario, y al menos en lo que respecta a los libros de microrrelatos publicados en papel, la imagen posee una importancia muy inferior. Se trata de una consecuencia lógica de, en mi opinión, varios condicionantes de la literatura escrita tradicional (adjetivo que aquí contrapongo a la hipermedial, ${ }^{2}$ la que se publica en internet). En primer lugar, es resultado del definitorio componente textual de la literatura; habitualmente se acepta que la imagen puede tener su lugar en la portada con una finalidad más comercial que artística, pero son pocos los casos en los que se integra en la trama. Incluso en los casos en los que el autor las emplea de manera rudimentaria, pienso por ejemplo en la página en negro de Tres tristes tigres (1967) de Guillermo Cabrera Infante o en los dibujos geométricos de Los detectives salvajes (1998) de Roberto Bolaño, se les considera como excentricidades del autor. Muchos de estos mecanismos de ruptura de la discursividad narrativa mediante la imagen tienen sus precedentes en las vanguardias; recordemos, por ejemplo, los caligramas.

La segunda razón que explica, a mi juicio, la escasa presencia de la imagen en la literatura publicada en papel es mucho más prosaica: su precio. No debemos olvidar que los libros son productos comerciales y, como tales, deben atenerse a los condicionantes del mercado e imprimir obras con cuadros o fotografías es bastante caro. A menudo, para evitar que el precio final alcance las cotas de los prohibitivos manuales de arte repletas de reproducciones a todo color, se opta por el blanco y negro ofreciendo una versión de menor calidad pero más asequible de la imagen. Este aspecto, que como todas aquellas relacionadas con el lado comercial de la literatura no debe ser soslayado por un análisis teórico, actúa como una especie de autocensura para el autor, que evita usar como paratexto una imagen a la hora de concebir el relato por lo difícil que le será convencer a su editor de la pertinencia de una edición más cara y algo más compleja técnicamente.

A pesar de su escasez, fueron varios los críticos que advirtieron de las enormes posibilidades de las imágenes como paratextos de los minicuentos y unos pocos autores los que las emplearon para acompañar sus narraciones brevísimas. De gran interés para poseer una visión amplia sobre el tema es el artículo de Francisca Noguerol titulado "Minificción e imagen: cuando la descripción gana la partida" (Noguerol, 2008). En él, esta especialista analiza libros ilustrados y viñetas cercanas a la minificción y señala que "la utilización de imágenes en textos

\footnotetext{
${ }^{2}$ Con el término "hipermedial" me refiero a aquellas publicaciones de internet que mezclan textos y elementos multimedia como imágenes o vídeos.
} 
breves narrativos se encuentra estrechamente relacionada con una serie de géneros vinculados a sus orígenes como categoría textual. Es el caso, en el Modernismo, del poema en prosa y el libro de viajes" (Noguerol, 2008: 187).

En un artículo del mismo libro colectivo que recoge las ponencias y comunicaciones del IV Congreso Internacional de Minificción celebrado en 2006 en Neuchâtel (Suiza), Irene Andres-Suárez estudia el que quizás sea el libro en el que mejor se observa la relación entre microrrelato e imagen: Cuentos del libro de la noche (2005) de José María Merino. Esta obra consta de ochenta y cinco minicuentos que tienen la particularidad de estar acompañados por otras tantas imágenes. Encontramos dibujos, ilustraciones, fotografías o cuadros del propio Merino o de otros autores y que funcionan como paratextos individuales del microrrelato con el que cada una de estas imágenes dialoga. Irene Andres-Suárez advierte de la importancia de estas imágenes para entender la intención del autor, ya que esta iconografía "constituye una vía muy eficaz para acceder a sus planteamientos estéticos y conceptuales" (Andres-Suárez, 2008: 373). El propio autor deja claro que todas las imágenes se integran en el proyecto global del libro en la nota que cierra el volumen: "Aunque soy responsable de todas [las ilustraciones], en varias he utilizado más o menos manipuladas imágenes de algunos artistas antiguos y modernos" (Merino, 2005: 167). Christoph Rodiek también ha analizado varios microrrelatos de Cuentos del libro de la noche y los define como "bimediales", término que define de la siguiente forma: "el microrrelato bimedial no sólo hace referencia a su pre-texto principal, sino que lo lleva incorporado. Este pre-texto incorporado es visual (grabado, dibujo, foto, etc.) y sirve de punto de partida a la narración verbal" (Rodiek, 2012: 191). Mediante esta técnica que señala Rodiek, Merino ofrece al lector la referencia intertextual visual al incorporarla como paratexto. Así, y por seguir el ejemplo que este crítico analiza, cuando el autor leonés escribe en "Nicolasito" (Merino, 2005: 156) sobre este personaje de Las meninas de Velázquez, no debe esperar, como el resto de los autores que emplean esta clase de referencias, que el lector recuerde el cuadro, sino que presenta un collage de la obra del pintor sevillano como paratexto para facilitar la recepción.

A pesar de su interés y de las enormes posibilidades que abre a otros autores, el libro de Merino se puede considerar una excepción en la minificción española y apenas encontró eco, quizás por su dificultad técnica o por su precio, en escritores posteriores. De hecho, en la antología que recogió los microrrelatos del propio Merino un par de años después, titulada $L a$ glorieta de los fugitivos (2007), aparecían reproducidos los textos de Cuentos del libro de la noche (2005) pero no las ilustraciones, denotando cierto desprecio hacia estos paratextos o simplemente una necesidad de abaratar costes de la edición. Entre los pocos precedentes a Merino en el uso de la imagen como paratexto en la minificción española debemos citar Neutral corner (1962) de Ignacio Aldecoa. En este breve volumen se mezclan textos brevísimos del narrador vasco con fotografías en blanco y negro de Ramón Masats sobre el tema de las prosas: el boxeo. Se trata de una verdadera joya bibliográfica que, si bien fue reeditada en 1996, hoy en día es muy poco conocida por los lectores y cultivadores de minicuentos.

El uso de la imagen como paratexto del microrrelato era, por lo tanto, un recurso de mucha utilidad y con grandes posibilidades para la minificción, como demostraron Merino y Aldecoa, pero de escasa frecuencia en los libros editados en papel por su dificultad técnica o 
por su precio. Estos dos condicionantes desaparecieron en la siguiente etapa del microrrelato, cuyo inicio podemos situar en torno a 2005 y que se caracteriza por la explosión que sufrió el género con internet. La popularización del género a partir del surgimiento de una gran cantidad de blogs que publicaban minicuentos provocó que este entrara en esa nueva fase.

\section{Los microrrelatos en Instagram}

Se trata de un lugar común afirmar que la minificción es, junto a otros como el aforismo y la poesía, el género que mejor se adecúa a internet. En palabras de Antonio Rivas, "para el microrrelato, los nuevos ámbitos de difusión de la cultura, esto es, el mundo de internet y los formatos digitales funcionarían como un hábitat, en principio, de grandes posibilidades, igualmente para su difusión, como para su creación, remodelación e hibridación" (Rivas, 2018: 221). Entre estas posibilidades que apunta Rivas estaría la presencia de la imagen, lo que lo convertiría, en palabras de Rosa María Navarro Romero, en un género "transmediático"; esta teórica lo explica con las siguientes palabras: "Otra ventaja que nos ofrece la plataforma virtual es la posibilidad de vincular textos e imágenes, realizando una combinación estética de elementos textuales, sonoros y visuales" (Navarro Romero, 2014: 8).

En el uso de la imagen como paratexto de una obra literaria, el cambio es sustancial y evidente en la literatura en internet: desaparecen tres de las dificultades que encontramos en la publicación en papel. En primer lugar, el precio de la edición deja de ser un problema; además de la gratuidad de la mayor parte de la literatura cibernética, el hecho de acompañar un texto de ilustraciones o fotografías no supone un gasto extra, ya que el píxel no distingue entre blanco y negro y color, al menos en épocas como la nuestra de banda ancha, como sí lo hace la tinta. El segundo problema, la dificultad técnica, también queda soslayada con las nuevas herramientas que los informáticos ponen al servicio de los escritores. Casi cualquier plataforma de publicación, desde los blogs hasta Twitter pasando por Wattpad, facilita al usuario con pocos conocimientos técnicos poder subir imágenes con mucha más sencillez que la que implica incluirla en la maquetación de un libro. En tercer lugar, los derechos de autor en lo relativo a las fotografías o cuadros apenas suponen un problema en internet, donde o bien directamente se toman sin más o, como mucho, se cita al autor. Además, para los más escrupulosos en el cumplimiento de las leyes, existe un banco de datos cada vez mayor de imágenes gratuitas o con derechos públicos (Creative Commons).

La eliminación de estas tres trabas fue rápidamente asimilada por los autores de minificción en la primera plataforma que emplearon: las bitácoras. En la blogosfera, que tuvo su esplendor en lo relativo a la publicación de microrrelatos en español entre 2006 y 2012 aproximadamente, los autores solían acompañar sus minicuentos de imágenes más o menos relacionadas con el contenido del texto. En la mayoría de los casos era simplemente una manera de hacer más atractiva su bitácora y no encontramos una relación tan estrecha de este paratexto con la trama como la que hallábamos en los libros de José María Merino e Ignacio Aldecoa.

Tras la decadencia de la blogosfera, los autores de microrrelatos encontraron nuevas plataformas para publicar sus textos en redes sociales como Twitter, Facebook o Instagram. Esta última, por su propia naturaleza asociada a la fotografía desde su nacimiento, es sin duda 
alguna donde el uso de la imagen como paratexto es más interesante. Recordemos que Instagram nace en 2010 y está orientada fundamentalmente a la publicación de imágenes y, recientemente, vídeos. En lo relativo a la literatura, esta red social ha acogido el desarrollo de algunos géneros que se amoldan a sus características (preponderancia de lo visual, publicaciones impactantes para destacar entre las demás, interacción de los usuarios, etc.) entre los que destaca la poesía. Tal desarrollo ha alcanzado la lírica en Instagram que se ha acuñado el término "instapoesía", definido por Concepción Torres Begines como "una manifestación artística incluida dentro de la corriente de readaptación de las formas clásicas a los nuevos medios, compartida en Instagram por jóvenes poetas que tratan temas actuales [...] y que tiene como objetivo una franja de lectores constituida por personas activas en redes sociales que comparten las publicaciones con sus seguidores" (Torres Begines, 2019: 43). Esta autora señala que los rasgos de este tipo de poesía serían "su brevedad (limitado a una sola imagen), un cuidado diseño visual, uso de un lenguaje simple e inclusivo y el predominio del verso libre" (43).

En el caso del microrrelato, su presencia en Instagram no es ni mucho menos tan abundante como el de la poesía. Quizás por esa tendencia a desechar la imagen como paratexto que estamos comprobando en la historia de la minificción o por la lentitud de adaptarse a una plataforma que, originalmente, no estaba destinada a la publicación de textos literarios, la publicación de microrrelatos en Instagram no ha sido tan mayoritaria como en los blogs, Facebook o Twitter. Sin embargo, la necesidad de los autores noveles de compartir sus historias brevísimas ha hecho que muchos de ellos opten por una red social tan mayoritaria como esta para encontrar a lectores interesados en sus textos. La búsqueda del hashtag \#microrrelato en esta web nos ofrece unos 120.000 resultados, lo que sumados a los 387.000 de \#microcuento nos muestra una cantidad enorme y sorprendente para estar ante una red eminentemente visual. Aun así, estamos lejos de los números de los hashtags asociados a la lírica que superan los cuatro millones (\#poema) o casi alcanzan los catorce millones de resultados (\#poesia, sin tilde).

De todas formas, no debemos asimilar siempre el uso de hashtags de este tipo con la pertenencia de una publicación a un género literario concreto; en muchos casos estamos simplemente ante una etiqueta que define metafórica o irónicamente la fotografía subida. En cualquier caso, y dejando de lado también aquellos hashtags que se usen con imágenes en los que el usuario está leyendo libros del género citado, la cantidad de textos literarios publicados cada día en Instagram es ingente. En el caso del microrrelato su presencia en esta, como en el resto de las redes sociales, es muy variada por varias razones entre las que podríamos citar la heterodoxa concepción según la cual muchos usuarios poseen del género o el propio carácter desenfadado que tiene la publicación en internet y que está asociada casi siempre a autores noveles que publican sin el riesgo (económico y de crítica profesional) que se suele vincular con la edición de libros en papel.

\section{Relaciones entre imagen y texto en los microrrelatos de Instagram}

Si algo define a Instagram frente al resto de las redes sociales es la preponderancia absoluta de la imagen. Si bien es cierto que la web permite que el usuario ofrezca extensas descripciones 
en sus publicaciones y los textos son una de las posibilidades que ofrecen las stories que duran veinticuatro horas, el grueso de lo que se sube cada día está formado por fotografías, ilustraciones, vídeos, cuadros, etc. Incluso si el usuario desea simplemente subir un microrrelato (o cualquier otro texto) sin ninguna otra fotografía a su página, debe hacerlo en formato jpg o similar, es decir, como una imagen.

Álvaro Llosa, en un interesante artículo en el que analiza la relación del microrrelato en Instagram con los memes literarios, ofrece una taxonomía de los cuatro tipos de cuentas que publican minificciones en esta y otras redes: la antología colectiva y el editor-antólogo; la antología individual y el diseño editorial de la puesta en página visual; antologías multimodales: de texto, imágenes, anotaciones autoriales e interacción en la red; y, por último, la antología colectiva cibertextual y el algoritmo antólogo (Llosa Sanz, 2019). A la hora de analizar el ejemplo que cita del tercer tipo de cuenta, una minificción titulada "La lista de Harris" del usuario@urbanosferas, Llosa señala lo siguiente: "la ilustración fotográfica es un reflejo visual del elemento clave que da título al microrrelato y que desencadena la acción narrativa, formando parte del relato al estar mencionado además en la anotación explicativa" (Llosa Sanz, 2019: 33). Como vemos, estamos ante un uso de la imagen como paratexto del microrrelato muy parecido al de José María Merino en Cuentos del libro de la noche y de Ignacio Aldecoa en Neutral Corner y que solo gracias a las posibilidades (técnicas, económicas y legales) que permite internet y que favorece Instagram se ha convertido en una tendencia importante en la minificción hipermedial frente a los pocos casos aislados que encontramos en la edición en papel.

Aunque un análisis completo del microrrelato en español en Instagram (en esta red social las barreras nacionales son más endebles que las idiomáticas) se escapa de los límites de este trabajo, sí creo que es interesante analizar varios casos concretos como ejemplos de las principales variantes que encontramos del cultivo del género en esta plataforma. Hallamos tres tipos básicos de publicaciones de minicuentos en Instagram: en la descripción, como imagen o híbridas, es decir, uniendo una imagen con un texto en la misma publicación.

Antes de analizar nuestro corpus creo que son necesarias unas cuantas aclaraciones. Debido a lo proceloso de este ámbito y aunque existen algunas cuentas antologadoras cuyos criterios podrían ser tenidos en cuenta, nos hemos limitado a escoger unos cuantos ejemplos que representen las distintas formas de presentar un microrrelato en Instagram. Este artículo no tiene un afán crítico ni pretende establecer ningún canon; se trata de un acercamiento meramente teórico al tema, por lo que los minicuentos han sido seleccionados sin tener en cuenta sus cualidades literarias ni estéticas (en el caso de las imágenes). Considero, incluso, que es interesante evitar este tamiz cualitativo para presentar una muestra aleatoria, determinada por el motor de búsqueda de la web, de la minificción que se publica en la red. Además, manejamos un número limitado de ejemplos en nuestro corpus, debido a los límites que este artículo posee y porque nuestra intención es que funcionen como ejemplos de las posibilidades que ofrece a los creadores de los microrrelatos el uso de la imagen en Instagram.

Por lo tanto, tan solo hemos tenido en cuenta tres requisitos en la elección de nuestro corpus: en primer lugar, que representen las distintas variantes de conjugación de imagen y texto que antes citábamos; en segundo lugar, que el autor haya usado el hashtag \#microrrelato 
o \#microcuento y, en tercer lugar, que estemos ante microrrelatos. Este último requisito puede parecer redundante con el segundo, pero muchos de los textos que aparecen junto a los hashtags genéricos antes citados no se ajustan a las características de la minificción narrativa. Como ya señalé en otro artículo al analizar el minicuento en Twitter, a menudo el autor da gato (un texto breve cualquiera sin narratividad) por liebre (un microrrelato) utilizando el hashtag erróneamente (Pujante Cascales, 2020: 10).

El primer tipo que analizaremos, ejemplificado en la IMAGEN 1, es aquel en el que el microrrelato ocupa la descripción de la fotografía. Se trata del uso básico de las publicaciones de Instagram, ya que prepondera la imagen y el texto aparece como un elemento secundario y casi accesorio. En el caso de incluir un minicuento, este subvierte su función con respecto a los del libro de José María Merino y adquiere un valor casi de paratexto, ya que parece acompañar al elemento principal de la publicación, que es visual y que es el que debe atraer la atención del usuario, que, solo después de haberse fijado en la fotografía, leerá la breve narración que la acompaña. En el caso de la IMAGEN 1, esta subordinación parece clara, ya que nos encontramos ante una fotografía bastante impactante, firmada además en la parte superior por el usuario y que por sí sola llama la atención. Este asombro visual se puede poner en relación con el uso de finales sorprendentes tan habituales en la minificción, especialmente en la que se publica en las redes sociales; en un ámbito tan sobresaturado de contenidos, el creador debe ofrecer algo que atraiga al receptor, sea mediante una original fotografía o con un giro inesperado en la trama. Sara Losada Coca ya advirtió de las confluencias entre el minicuento y la fotografía humanista (desarrollada principalmente en los años treinta, cuarenta y cincuenta del siglo XX) en un artículo en el que analizó sus semejanzas y en el que concluía que "la fotografía humanista presenta numerosos rasgos similares a las técnicas del microrrelato y que, en síntesis, aluden a su gran capacidad expresiva de corte intimista" (Losada Coca, 2018: 170).

En la IMAGEN 1 el microrrelato establece una clara relación semántica con la imagen, ya que parece crear una pequeña fábula que explique lo original, un árbol solitario en mitad de una ladera rocosa, de la imagen. Aunque en otros ejemplos la relevancia de la imagen no es tanta como en este caso, por elegir fotografías más anodinas o que simplemente ilustren un texto previo, este tipo de disposición siempre ofrece cierta subordinación del texto a la imagen; frente al poder sugestivo de esta, el minicuento queda en un segundo lugar por su carácter de pie de foto en un cuerpo de letra nada llamativo. 


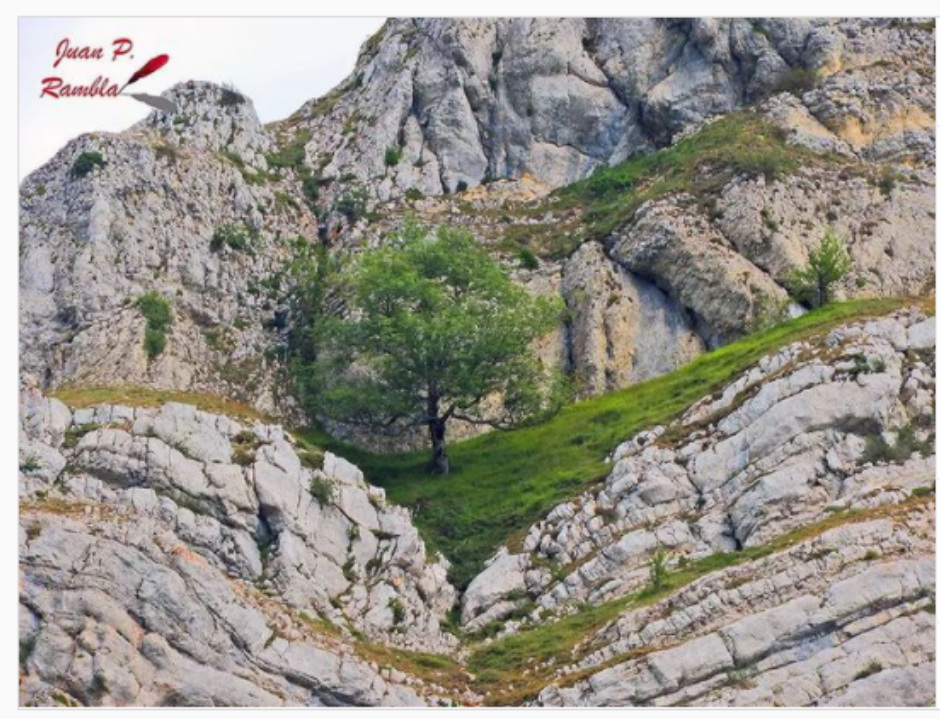

IMAGEN 1, https://www.instagram.com/p/CS9SQfxDL71/

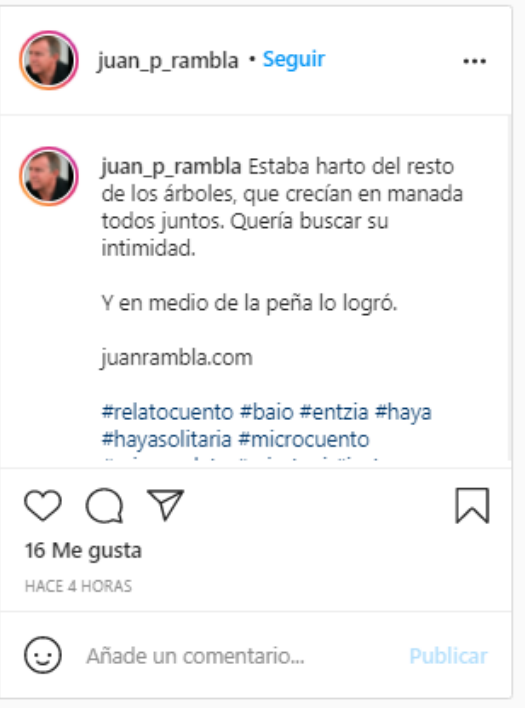

(Consultado el 26/08/2021)

Para evitar que el microrrelato tenga que ocupar ese lugar secundario que observábamos en la IMAGEN 1, los usuarios han optado por una solución muy sencilla y eficaz: convertir sus textos en imágenes. Se consigue así que el texto sea más llamativo y ocupe el lugar que las fotografía e ilustraciones copan en una red social eminentemente iconográfica como es Instagram. En esta conversión del texto en imagen encontramos una tipología intermedia entre la primera que hemos analizado y la tercera (en la que solo hay texto convertido en imagen). Se trata del tipo de publicación que ejemplifican las IMÁGENES 2 y 3 (que pertenecen al mismo post) y que consiste en subir el texto del microrrelato y la imagen que sirve de paratexto. En el caso del minicuento y la fotografía de las IMÁGENES 2 y 3 , de nuevo hallamos esa estrecha relación entre la trama del relato, su título y la fotografía que las acompañan: los tres tienen como referente la misma estatua de un sireno. Tenemos, por lo tanto, un microrrelato acompañado de dos paratextos: uno textual (el título) y uno visual (la fotografía). Se consigue así, al igual que ocurría en la publicación de la IMAGEN 1, que estas minificciones se pueden asimilar a lo que Torres Begines definía como género transmediático. 

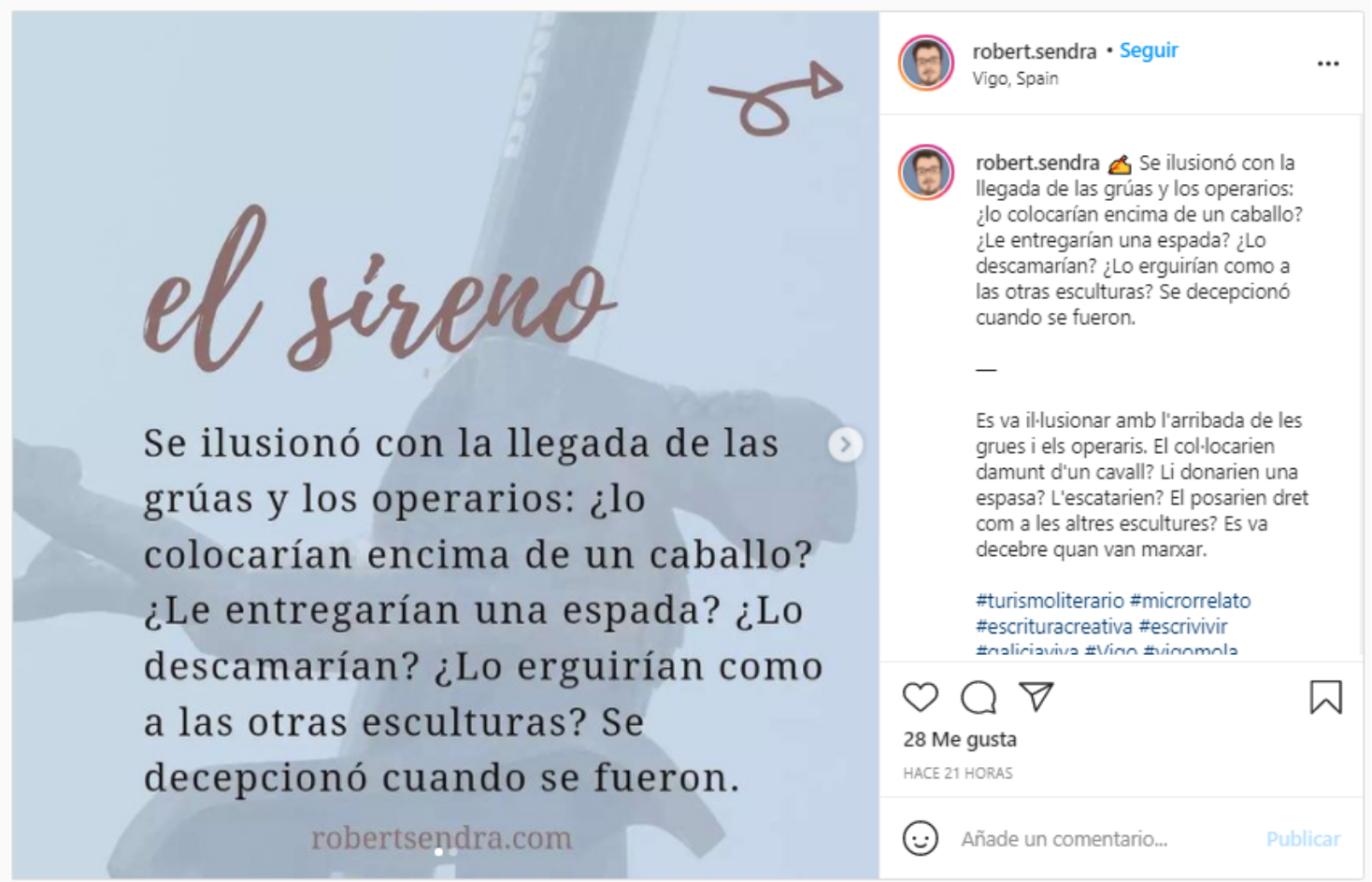

IMAGEN 2, https://www.instagram.com/p/CS7hLdYNlqg/ (Consultado el 26/08/2021)
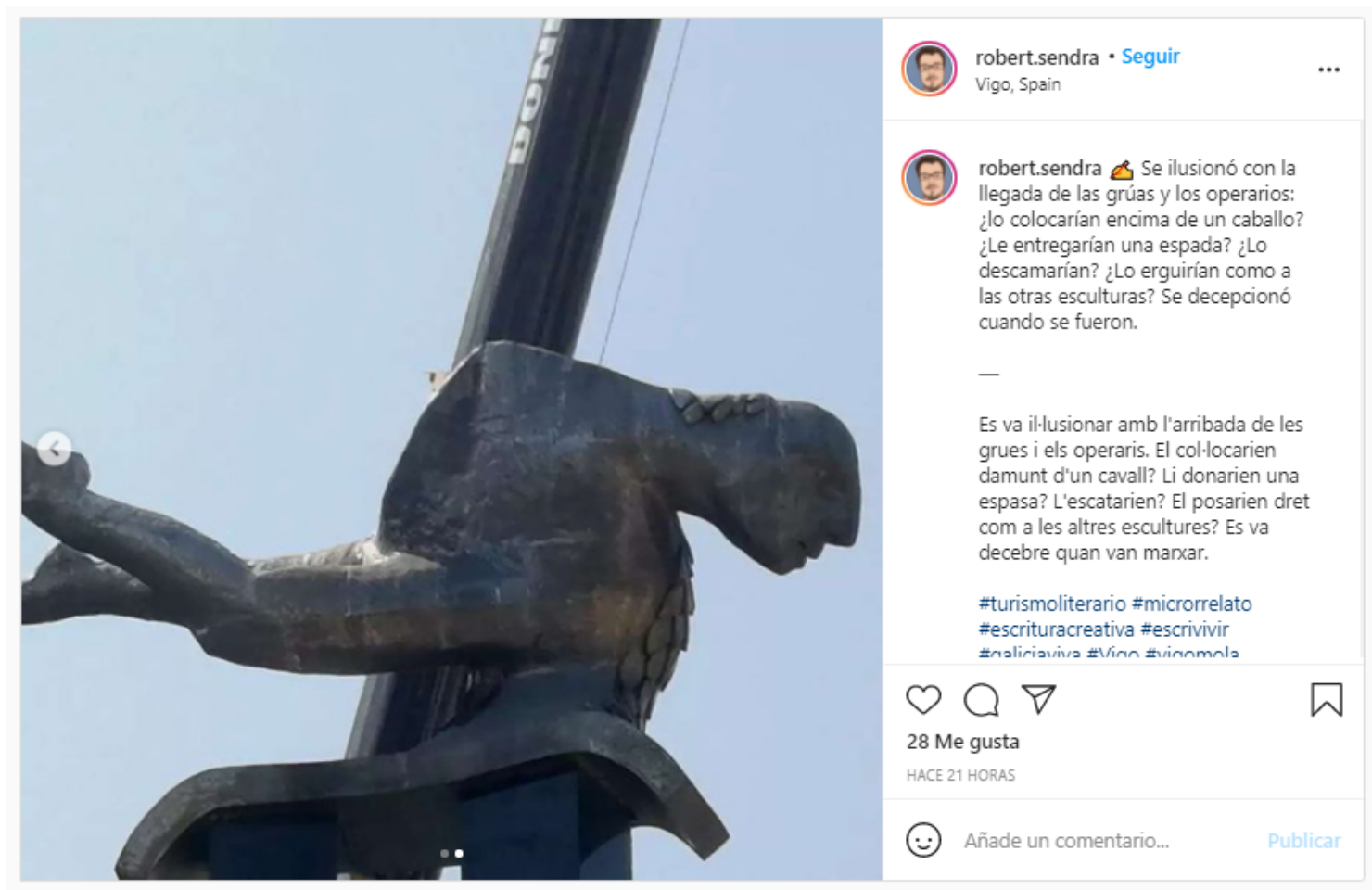

IMAGEN 3, https://www.instagram.com/p/CS7hLdYNlqg/ (Consultado el 26/08/2021)

Este tipo de posts híbridos que hemos ejemplificado con las IMÁGENES 2 y 3 poseen muchísimas variantes en Instagram. Los autores son conscientes de que el componente iconográfico es el primordial en esta red social y para atraer a los lectores o para conjugar la publicación del texto con los condicionantes de esta plataforma, mezclan de muy diferentes 
formas el microrrelato con imágenes. A menudo, los usuarios crean, con mayor o menor pericia técnicas, imágenes en las que insertan una fotografía junto al minicuento. En estos casos, como podemos comprobar en la IMAGEN 4, la imagen actúa como un paratexto que acompaña a la narración, que es la que adquiere un mayor protagonismo. A veces, la imagen tiene un componente incluso más secundario, ya que no busca tanto explicar el significado del texto como simplemente embellecer el post; es lo que ocurre en el minicuento de la IMAGEN 5, donde los dibujos de dos serpientes acompañan una narración (que continúa en las siguientes imágenes) sobre Eva.

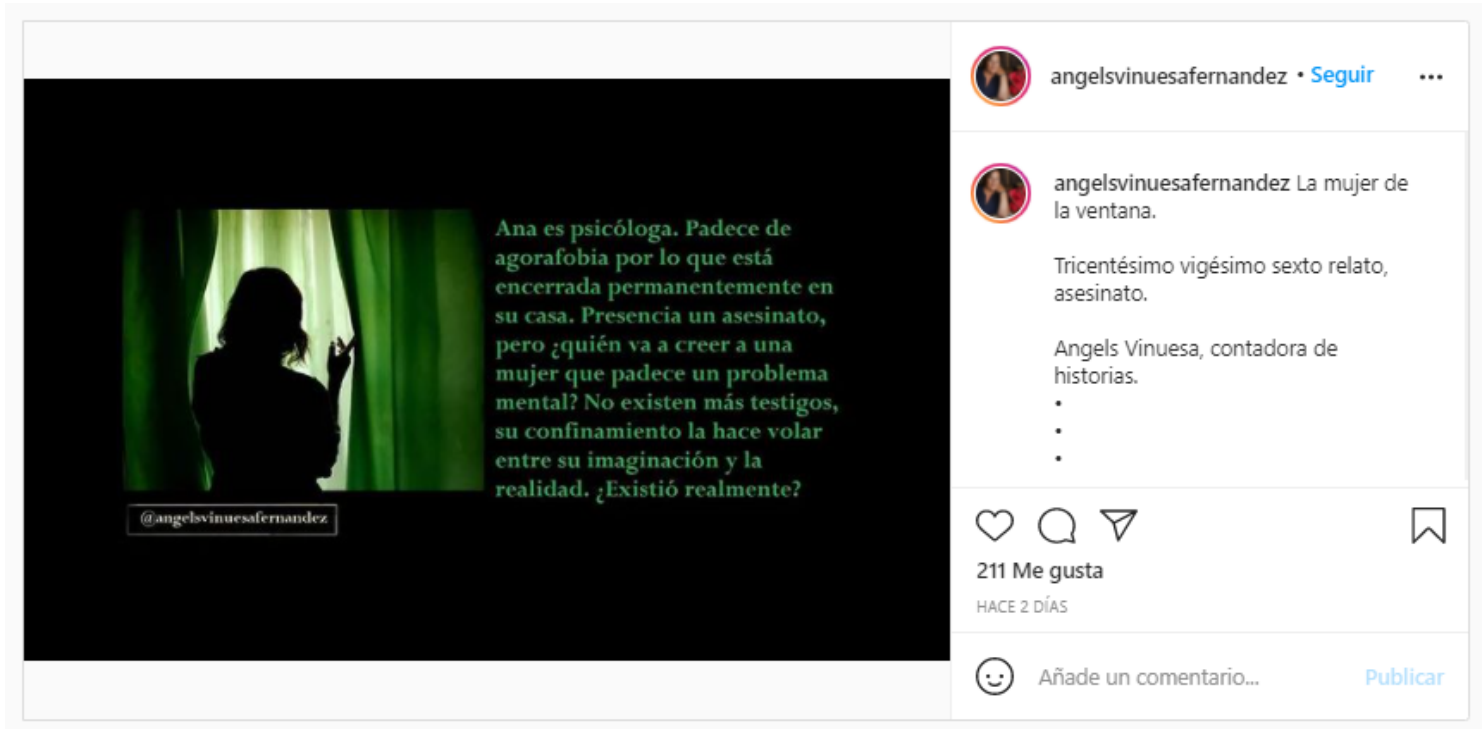

IMAGEN 4, https://www.instagram.com/p/CS4Q6 qDD1h/ (Consultado el 26/08/2021)
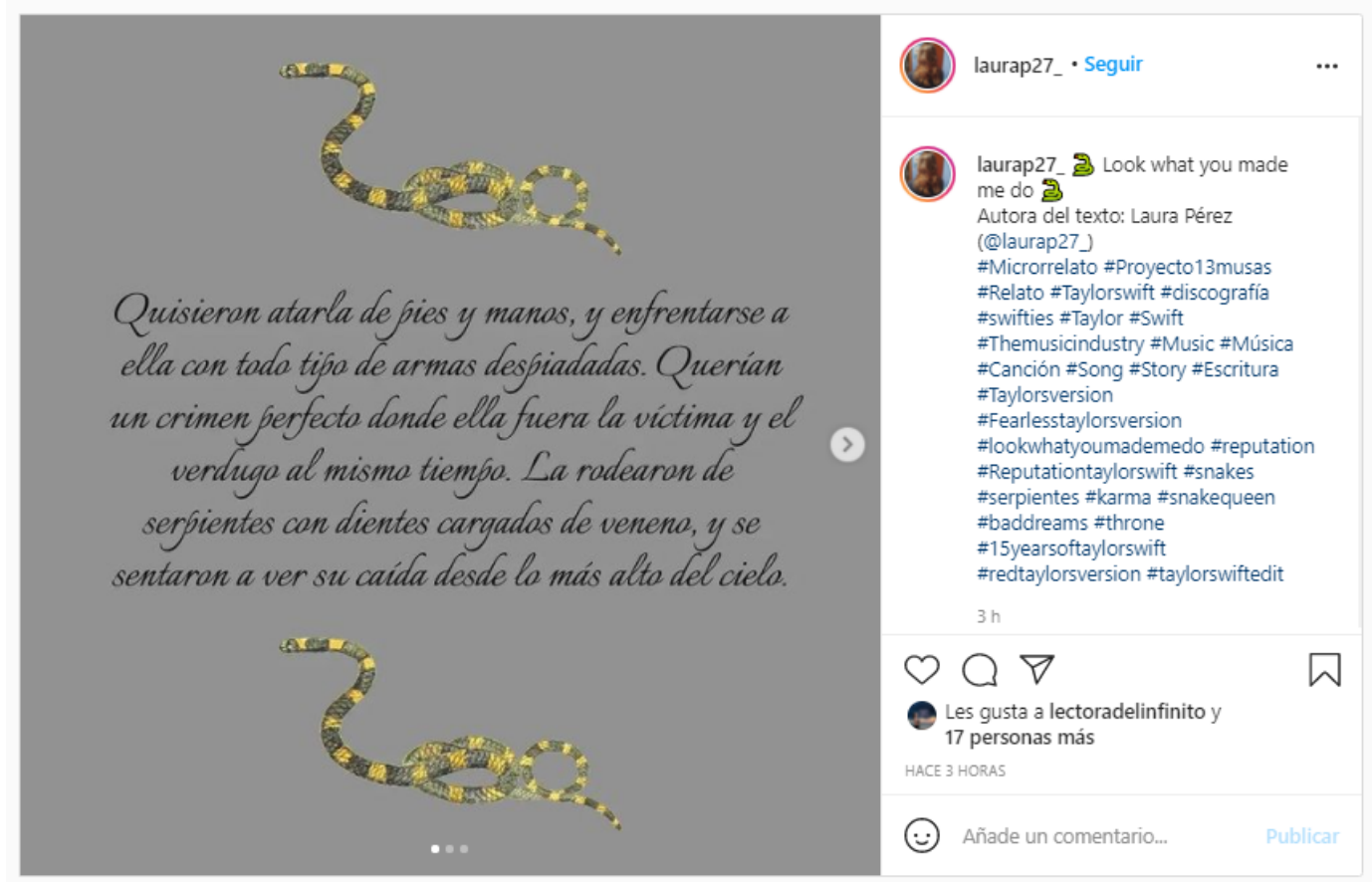

IMAGEN 5, https://www.instagram.com/p/CS9Z272jlcm/ (Consultado el 26/08/2021) 
En los ejemplos anteriores se puede constatar un rasgo fundamental de los microrrelatos publicados en Instagram, salvo los que aparecen en la descripción como en la IMAGEN 1, como es la relevancia de la tipografía. El componente visual de esta red social permite el uso de fotografías como paratexto, pero también fomenta que los autores, buscando siempre impacto en los lectores, cuiden más que en otras redes sociales elementos como el tamaño de letra, el tipo, el color de fuente o de fondo. Se trata de aspectos secundarios desde el punto de vista literario, pero que adquieren especial relevancia en muchas publicaciones, como en la que observamos en la IMAGEN 6. Se trata de la tercera y última manera de publicar minificciones propias en Instagram: usar el texto como imagen, pero no acompañándolo, como en los anteriores ejemplos, de ningún elemento iconográfico. La ausencia de imágenes lleva a los autores a tener especial cuidado con el tipo de letra, la disposición del texto o los colores empleados, en esa búsqueda de una relevancia estética tan asociada a esta red social.

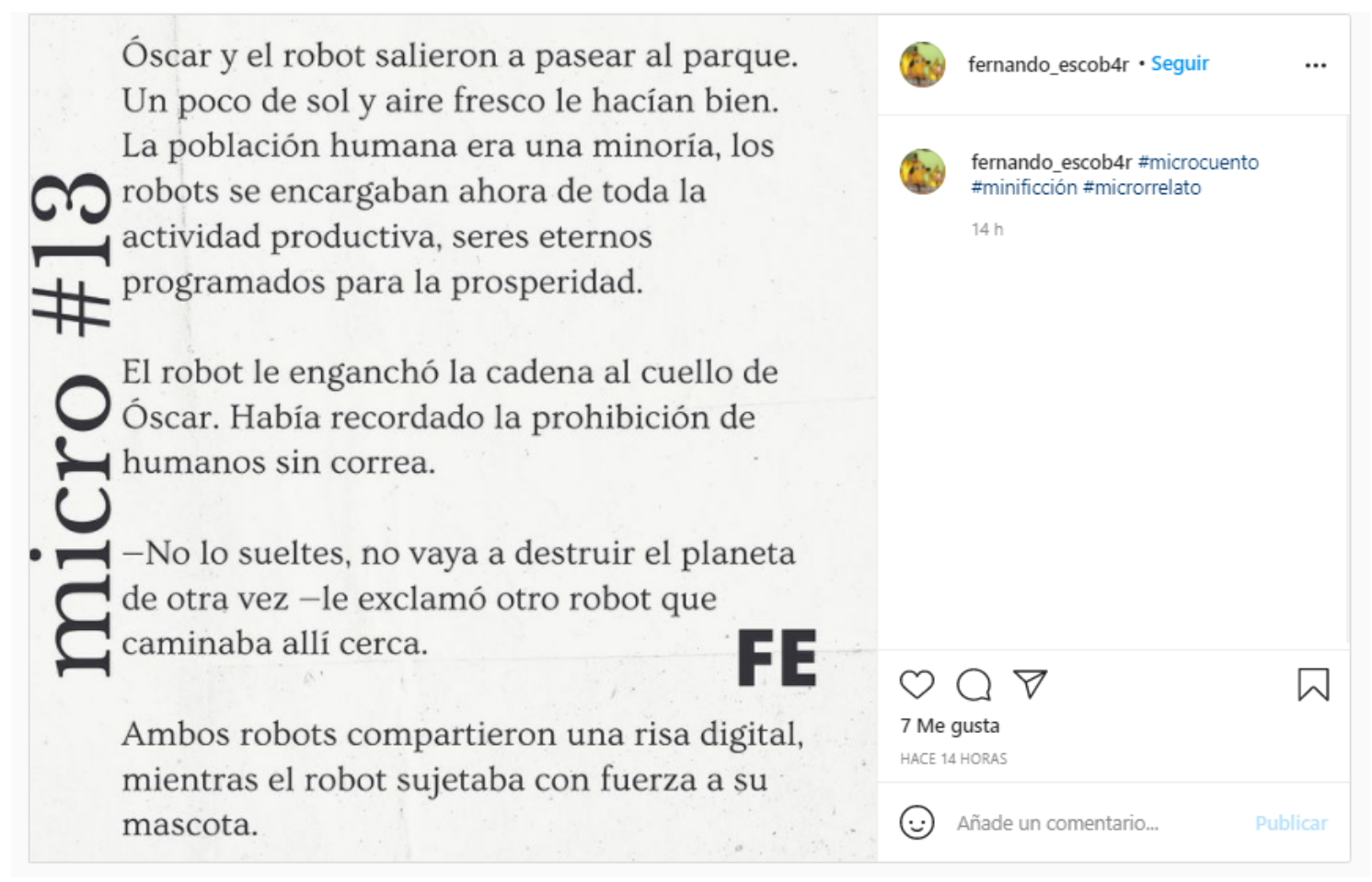

IMAGEN 6, https://www.instagram.com/p/CS8KOfgrkID/ (Consultado el 26/08/2021)

En esta breve taxonomía de la forma de publicar microrrelatos en Instagram y su relación con las imágenes podríamos añadir un cuarto tipo: las fotografías a minicuentos en libros. Sin embargo, creo que se trata de una forma de compartir minificciones diferente a las otras tres, ya que en la inmensa mayoría de los casos no estamos ante narraciones propias, sino textos de autores conocidos. Es lo que ocurre, por ejemplo, en la publicación de la IMAGEN 7, en la que el usuario comparte una fotografía de un libro en la que aparece el famoso microrrelato "La oveja negra" de Augusto Monterroso junto a un comentario propio. Se observa mediante este tipo de publicaciones, bastante habituales en Instagram, cómo las redes sociales fagocitan 
cualquier medio, digital o analógico, y permiten llegar a los poemas o microrrelatos a un público que, en la mayoría de los casos, no leería estos libros.

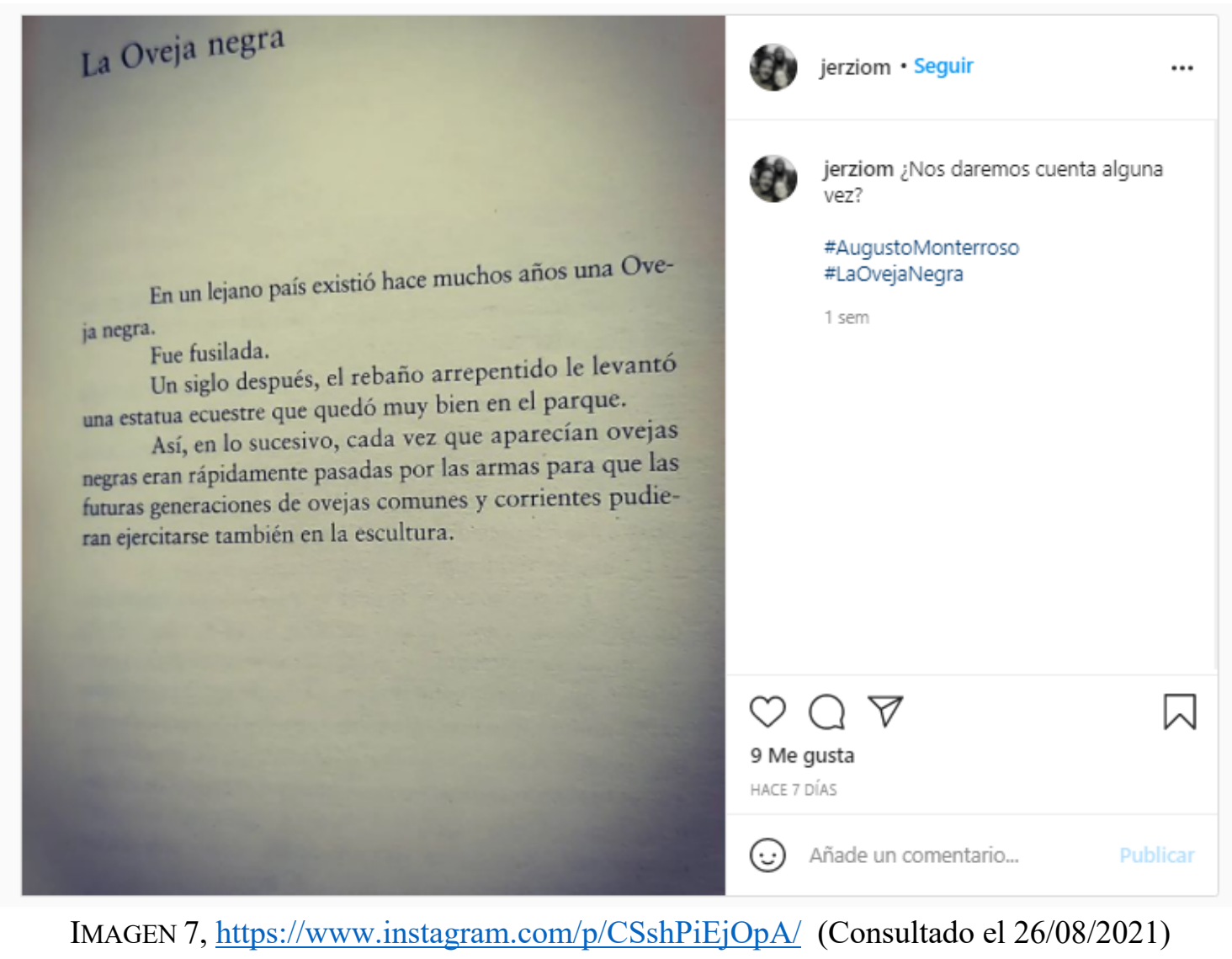

\section{Conclusiones}

En un campo aún tan novedoso como es la literatura hipermedial, es difícil realizar afirmaciones tajantes, máxime cuando se trata de un ámbito marcado por la heterogeneidad y el cambio constante. Sin embargo, y en el caso concreto que nos ocupa, el análisis de las relaciones entre imágenes y microrrelatos en Instagram nos ha deparado varias conclusiones. En primer lugar, que internet ha favorecido el uso de fotografías, ilustraciones y cuadros como paratextos de la minificción; lo que en la literatura en papel era un recurso muy interesante pero escasísimo por cuestiones técnicas y pecuniarias, se ha convertido en un mecanismo habitual en la minificción cibernética y fundamental en la publicada en Instagram. En esta red social hemos apreciado que, por su propia naturaleza, la imagen puede adquirir un protagonismo mayor que el texto al que supuestamente acompaña y que este debe dotarse de una serie de aspectos tipográficos que llamen la atención del lector.

Estamos, en definitiva, ante una pequeña muestra de que internet ha supuesto un giro copernicano a la literatura, enfrentando la forma de entenderla nacida tras la imprenta a un nuevo paradigma. Aunque reconocemos las enormes oportunidades que abren redes sociales como Instagram al microrrelato, como hemos constatado en el uso de la imagen como paratexto, 
no debemos ocultar los problemas que también provocan en el desarrollo del género. Estos, en el caso de la minificción, se pueden concretar en dos: por un lado, la falta de filtro (y no precisamente el visual, sino el de un editor) que provoca la saturación de la red de textos de ínfima calidad; y, por otro, cierto desconocimiento de los rasgos definitorios del género, como se puede constatar en el uso erróneo de hashtags que etiquetan textos que son breves, sí, pero no microrrelatos al carecer de narratividad.

\section{Bibliografía}

ANDRES-SuÁREZ, Irene (2008): "El universo iconotextual de José María Merino: Cuentos del libro de la noche". En Irene Andres-Suárez y Antonio Rivas (eds.): La era de la brevedad. El microrrelato hispánico. Palencia, Menoscuarto: 371-396.

GENETTE, Gérard (1989): Palimpsestos. La literatura en segundo grado. Madrid, Taurus.

IWASAKI, Fernando (2004): Ajuar funerario. Madrid, Páginas de Espuma.

LOSADA COCA, Sara (2018): "La fotografía humanista como germen microficcional". Microtextualidades, $\quad 4: \quad 152-174 . \quad$ DOI: https://doi.org/10.31921/microtextualidades.n4a13

LlosA SANZ, Álvaro (2020): "De microrrelatos y memes literarios en las redes sociales: estrategias de edición digital en la minificción multimodal". Microtextualidades, 7: 2645. DOI: https://doi.org/10.31921/microtextualidades.n7a2

Merino, José María (2005): Cuentos del libro de la noche. Madrid, Alfaguara.

NAVArro Romero, Rosa María (2014): "Literatura breve en la red: el microrrelato como género transmediático". Tonos Digital, 27: 1-12.

Noguerol, Francisca (2008): "Minificción e imagen: cuando la descripción gana la partida". En Irene Andres-Suárez y Antonio Rivas (eds.): La era de la brevedad. El microrrelato hispánico. Palencia, Menoscuarto: 183-206.

Pujante Cascales, Basilio (2008): “Minificción y título”. En Irene Andres-Suárez y Antonio Rivas (eds.): La era de la brevedad. El microrrelato hispánico. Palencia, Menoscuarto: 245-259.

--- (2020): “El autor implícito en los microrrelatos publicados en Twitter". Tropelías, 34: 452470.

RIVAS Bonillo, Antonio (2018): "Dibujar el cuento: relaciones entre texto e imagen en el microrrelato en red". En Ana Calvo Revilla (coord.): Elogio de lo mínimo. Estudios sobre microrrelato y minificción en el siglo XXI. Madrid-Frankfurt am Main, Iberoamericana-Vervuert: 221-241. DOI: https://doi.org/10.31819/9783954876112$\underline{010}$

RoDIEK, Christoph (2012): "Microrrelato e imagen. El caso de José María Merino". Siglo XXI, 9-10: 189-202.

TORRES BEGINES, Concepción (2019): "Algunos apuntes sobre el fenómeno de la instapoesía". Revista Inclusiones, VI, número especial: 23-47. 
(C) Basilio Pujante Cascales

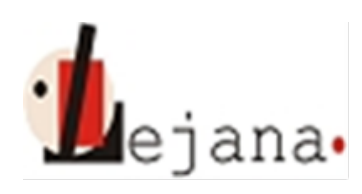

http://ojs.elte.hu/index.php/lejana

Universidad Eötvös Loránd, Departamento de Estudios Hispánicos

1088 Budapest, Múzeum krt. 4/C 